\title{
Actors, TARgets, AND Guardians: Using Routine Activities TheORY TO EXPloRe the 2008 Decision to Prorogue Parliament in CAnada ${ }^{1}$
}

\author{
JOHANNES WHEELDON
}

\begin{abstract}
While a number of scholars have offered a variety of constitutional critiques and political analyses for the 2008 prorogation of parliament, to date no comprehensive theoretical exploration has been attempted. In addition to the widespread agreement that the use of prorogation to avoid a potential nonconfidence vote was problematic, some have acknowledged that efforts to undermine the role of parliament in Canada have become routine. Combined with the role nationalistic tensions played in justifying such a profound departure from the principles of responsible government, this paper accepts the view that the 2008 decision to prorogue parliament constituted a "harm." Using routine activities theory it explores the events before, during, and after prorogation based on the confluence of a motivated actor, a suitable target, and the lack of a capable guardian. While this theory frames past events in a new way, of specific value is how the theory can be used to begin to chart a course to correct what has been called a dangerous constitutional precedent.
\end{abstract}

Key Words: routine activities theory; prorogation; constitutional studies; responsible government

Résumé. Bien que de nombreux spécialistes aient formulé diverses critiques constitutionnelles ainsi que des analyses politiques concernant la prorogation du parlement de 2008, aucune étude théorique approfondie n'a jusqu'à présent été entreprise. Il est couramment admis que le recours à la prorogation de manière à éviter un vote de censure est problématique; d'autre part, on a reconnu que les tentatives pour diminuer le rôle du parlement sont devenues systématiques.

1. Acknowledgements: This paper grew out of a number of discussions, arguments, and debates. I would like to thank Florian Bail, Marcus Felson, David Brock, Jon Heidt, Walid Madhoun, Jean-Bernard Robichaud, Peter Russell, and John Whyte for their comments on this manuscript. I would also like to thank Kevin Haggerty and Laura Botsford for their interest and editorial support. Finally, and especially, I want to thank Helen Forsey for her suggestions, comments, and useful critiques. Any remaining errors are my own.

C Canadian Journal of Sociology/Cahiers canadiens de sociologie 36(1) 2011 
Axé sur le rôle que les tensions nationalistes ont joué pour justifier un tel écart des principes du gouvernement responsable, cet article reconnaît que la décision de proroger le Parlement en 2008 est un "tord". Au moyen de la théorie des activités récurrentes, l'article analyse les événements antérieurs, contemporains et postérieurs à la prorogation sur la base de l'interaction d'un acteur intéressé, d'une cible appropriée et d'un manque d'arbitre qualifié. Tandis que cette théorie propose une nouvelle interprétation de ces événements, il est important de remarquer qu'elle permet peut-être de corriger ce que l'on a nommé un dangereux précédent constitutionnel.

Mots clés: théorie des activités récurrentes; prorogation; études constitutionnelle; gouvernement responsable

\section{INTRODUCTION}

Time he 2009 decision by the Harper government to request that parliament be prorogued was loudly criticized from coast to coast and among columnists of all political stripes. By contrast, few expressed the same concern about the 2008 prorogation, although the outcome of the governor general's decision at that time was far more significant. Having lost the support of all opposition parties, Prime Minister Stephen Harper delayed a nonconfidence vote by asking Governor General Michaëlle Jean to prorogue parliament. When she assented, Harper was able to avoid this vote by circumventing principles of responsible government inherent within Canada's parliamentary system of governance. While this decision was widely commented upon by political scientists and constitutional scholars at the time, Canadians themselves seemed largely uninformed.

The official narrative is that while the 2008 decision to prorogue parliament may have strained constitutionality, it was justified by the global economic downturn and the political unacceptability of the proposed coalition between the Liberals and New Democratic Party, supported by the Bloc Québecois (Russell and Sossin 2009). Yet almost immediately cracks within this conventional wisdom emerged. Noted political scientists have demonstrated how a pattern of political populism has undermined democratic notions of responsible government (Smith 2009; Weinrib 2009) and constitutional scholars have argued the 2008 decision by the governor general will have a profoundly negative impact on Canadian governance going forward (Heard 2009; Miller 2009). It is safe to say the legitimacy of the 2008 decision remains contested. Even defenders who justify the outcome of the crisis that emerged between December 2008 and January 2009 have acknowledged the problematic means by which it was realized (Cameron 2009). While these contributions are valuable, they are rooted within specific fields that often resist 
the multidisciplinary potential of more pragmatic approaches to public policy (Rorty 1999). Without a unified theoretical basis and compelling narrative to better engage the electorate, existing analyses will get lost and their lessons go unlearned.

This paper applies theoretical contributions drawn from sociology and criminology to explore the 2008 prorogation. By relying upon existing treatments and past analyses, I unpack notions of responsible government and demonstrate how the prime minister's prorogation request represented the culmination of a pattern of parliamentary disregard, relied on the manipulation of nationalistic tensions, and had the effect of up-ending core principles of responsible government based on an unexplored and untested theory of an unitary executive. By using a framework based on routine activities theory (RAT), this paper argues that the decision to prorogue parliament was the result of a confluence of three factors. These included: Stephen Harper as a motivated actor, the Canadian parliament as a suitable target, and the absence of a capable guardian, in this case Governor General Michaëlle Jean.

\section{Responsible Government and Prorogation: Contesting Constitutional Principles}

In Canada, as a constitutional monarchy, it is the Crown that acts as head of state and oversees the parliamentary system based on the principle of responsible government. Responsible government, in general terms, is a system making the government responsible to the electorate. In Canada, the executive is accountable to the House of Commons; those who exercise executive power need the support of the House to use that power (Smith 2009). If a government loses the confidence of the House, it is an important, though unwritten, constitutional convention that it either resign or request dissolution of parliament to call an election (Forsey 1990).

In a constitutional monarchy, the duties of head of state and head of government are distinct. Canada's head of state is Queen Elizabeth II, but the queen's Canadian duties are normally deputized to the governor general and lieutenant governors in each province. As the queen's representative, each embodies the power of the crown and has substantial constitutional authority (Roberts 2009). Federally, the governor general not only presides over the swearing-in of the prime minister, the chief justice of Canada, and cabinet ministers, but also summons, prorogues, and dissolves Parliament, delivers the Speech from the Throne, and gives royal 
assent to all legislation. The governor general almost always acts only on the advice of the prime minister and the government of the day. ${ }^{2}$

One of the most important responsibilities of the governor general is to ensure that Canada always has in office a prime minister and a government that has the confidence of the elected parliament. This responsibility is embodied in the governor general's reserve powers. The general rule, defined through generations of convention and precedent, is that the governor general is bound to interfere as little as possible in the governing process, acting only on the advice of the prime minister (Heard 2009). In exceptional circumstances, when the government appears to have lost the confidence of the House, that advice may be constitutionally questionable, and the governor general may exercise her reserve power to refuse the advice (Forsey 2010:4-5).

While the nature of the reserve powers, specifically as they pertain to the dissolution of parliament, has been the basis of some debate in Canada (Forsey 1943; Hogg, 2007), until 2008 there was no precedent for their use in the case of a request to prorogue. Prorogation is normally a simple and routine procedure to end a parliamentary session when "both Houses have finished a session's business" (Forsey 2010:47). During the period of prorogation all government bills cease to exist and all committee work stops; this makes sense when the business of the session is finished. It is clear that the governor general has the power to prorogue parliament based on the advice of the prime minster (Russell and Sos$\sin 2009$ ), and that no governor general ever refused a prime minister's advice to prorogue Parliament (Hogg 2010). In 2008, however, Harper's request for prorogation on 4 December 2008, barely one month into the new parliament, was made while a vote of confidence was pending (Miller 2009). What still provokes debate is whether the governor general was justified in substituting her and her advisors' judgment for the will of parliament and by extension of the Canadian people.

A major challenge in addressing this question is that Canada's system of responsible parliamentary government has operated for more than a century on the basis of unwritten rules and principles, referred to as "constitutional conventions." The efficacy of these constitutional conventions has depended very much on their acceptance by Canadian political leaders (Russell 2009) and the events of 2008 suggest a departure from the centuries-old understanding of the rules that have ensured the democratic operation of our parliamentary institutions. Prorogation in these circumstances was presented without a clear precedent, theoretical

2. Of some interest is the controversy that ensued when the governor general's website was updated with the history and clear outline of the roles and functions of the crown in Canada. See Boswell (2009). 
basis, or the kind of debate or deliberation one might assume would be necessary to sanction such a grand departure from Canadian parliamentary tradition.

While precedents, constitutional or otherwise, should never be accepted as sacrosanct, the suggestion that constitutional conventions are only effective as rules of proper conduct when the relevant actors accept that they are bound to observe them is problematic. It allows fundamental principles of parliamentary democracy to be ignored, even discarded, for short-term political advantage and without any kind of democratic process to remake Canada's system of governance. What is to be done when an institution of government begins to reimagine and redefine centuries of tradition based on political self-interest? To what extent can a normative judgment be made about such maneuvers? Why should Canadians care?

This paper concurs with the view that the use of prorogation in 2008 represented the culmination of "a pattern of disregard by Harper of a number of deeply embedded constitutional principles and practices" (Weinrib 2009:64-65). Yet the acceptability of the use of prorogation might be seen as more than a mere constitutional debate among scholars. I argue that the way prorogation was used in 2008 constituted a harm to the principles of responsible government in Canada because it: a) undermined parliament's central role in Canadian governance; b) relied on nationalistic tensions that had the effect of delegitimizing a political minority in the House of Commons; c) appeared to sanction a larger attempt to reform Canada's constitution without debate, discussion, or the participation of the Canadian electorate. If one accepts this definition of harm, more attention must be paid to how this event can be framed, explored, and perhaps confronted.

\section{Toward an Explanatory Model and Routine Activities Theory}

In order to analyze the harm done to the parliamentary system and political culture by the tactical use of prorogation, one might look at how theories of harm are used in sociology and criminology. One approach of immediate utility is the routine activities theory (RAT) proposed by Lawrence Cohen and Marcus Felson (1979). Connected to environmental criminology in which the question of the "place" of criminal events is central, this approach builds on the idea that criminal events occur where opportunities for crime exist. These might include where people congregate, such as work, school, home, and in transit between these places (Brantingham and Brantingham 1984). Cohen and Felson's (1979) con- 
tribution goes further in defining a criminal "opportunity" by arguing that three requirements need to be present for a crime to occur.

The first requirement, a motivated or likely offender, is a person who commits a crime based on a rational actor model of maximizing human advantage (Akers and Sellers 2004:26). The second requirement, a suitable target, is connected to the accessibility of the target and the ability to repel the attack (Miller et al. 2007:100). The last requirement, an absence of a guardian, refers to the lack of someone or thing that can prevent a crime from occurring. It may be formal - a police officer or citizen witness, or informal - a video camera, streetlights, or simply an ordinary citizen going about their daily lives (Clarke and Felson 1993). One value of routine activities theory is that it demystifies crime and criminals. By challenging prior explanations of crime that emphasized criminal intentions without considering in detail the circumstances in which criminal acts occur, RAT offers practical means to repel crime. By building on older theories from other disciplines (Newman 1972), it can suggest ways in which citizens have a shared responsibility for the spaces and interactions around them (Jacobs 1961).

Critics have argued that RAT amounts to an academic blaming of victims for the crimes committed against them (Meier and Miethe 1993) and there is an element of the theory that connects victim lifestyles to the commissions of crimes (Robinson 2004). Others argue RAT offers yet another attempt to administer, manage, and control crime (Wilson 1975), rather than trying to understand or explain it (Garland 2001). It cannot be denied that the assumption that potential offenders are always out there can feed fears about crime and undermine a more nuanced understanding of the broader societal factors involved in defining, enforcing, and contesting crime (Haggerty 2004). RAT focuses on crime prevention through the "situational" identification of risks and alteration of opportunities (Clarke 1997). It is hard to doubt the influence of theories based on the notion that criminal behaviour is normal and that criminals are rational (Cornish and Clarke 1986). Yet by accepting that only one application of RAT exists, critics may miss the "opportunities" provided by broadening routine activities thinking.

One of the aspects often overlooked by critics is the theory's position that without any one of the connected elements harms are less likely to occur. Traditionally, of course, this has led to a focus on target hardening to reduce the number or suitability of targets, or on expanding guardianship by hiring more police or installing video cameras. However, existing application of this theory to practices and approaches need not be definitive or exclusive. A more imaginative use of the theory could challenge the notion that those who commit crimes for short-term gain, to feed 
drug habits, or as a result of complex intimate relationships are rational. Creatively framed, RAT could justify prison education, methadone treatment, and respectful relationship programs. Instead of accepting first order applications of theories, some of the next generation of criminology scholars are investigating and building on these influential works. A focus ought to be how on these theories can be challenged, and revised to serve socially useful ends, and practical cost effective policy (Wheeldon and Heidt 2007; Wheeldon 2009).

While RAT may provide a simplistic account of criminals as rational actors, there will always be a small group of individuals who believe they are special, and that the "rules" do not apply to them. For this group, there may be value in considering how the other elements of this theory can reduce the loss, hurt, and harm caused by crime. Applying theories, approaches, and orientations from one discipline to another has limitations (Heidt 2003), but a more pragmatic approach to cross pollination in the social sciences is both desirable and necessary (Wheeldon 2009). Without sacrificing theoretical consistency and suitability, a more pragmatic application of theories may allow social scientists to challenge the perceived irrelevance of their contributions (Wheeldon and Heidt 2007).

Cohen and Felson's influential paper defining RAT (1979) considered the influence of broad social changes on macro level crime rates based on archival data. While influential, this was only one approach used to apply routine activities thinking; a year before that paper was published, RAT was applied to consumer behavior (Felson and Spaen 1978). In the last two decades since it emerged, a variant of this approach has been applied to topics as diverse as suicide (Clarke and Lester 1988) and terrorism (Clarke et al. 2006), and has influenced a number of other scholars interested in a broader understanding of the social ecology of crime. Based on the call for a return to pragmatic approaches to public policy and academic interactions (Rorty 1999), this paper applies yet another novel application of the theory by using it to frame, better understand, and attempt to address the harm caused by the 2008 decision to prorogue parliament.

\section{Applying the Theory: Actors, Targets, and Guardians}

In applying RAT to the decision to prorogue parliament, it may be useful to reframe some of the terms. Rather than a "crime," in this paper I refer to the events of 2008 as a "harm." In keeping with the theory, however, in which crime/harm is seen as a rather ordinary and common occurrence it is necessary to connect prorogation with other efforts to undermine Canada's constitutional conventions. While both the Liberals 
and Conservatives have been "playing fast and loose" with various constitutional principles and conventions in the last decade (Levy 2009:19), Stephen Harper has continued this practice by undermining parliament in unprecedented ways (Levy 2009; Weinrib 2009). While critics of the prime minister's actions and the governor general's inaction have presented their concerns using stark language, the utility of the RAT model may be discounted unless it is applied with some restraint. In this paper, I have reframed the language of RAT with regard to both the prime minister and governor general.

In the place of the motivated "offender" language of RAT, and to build on rational choice theories in economics and political science, the prime minister's actions are described in this paper as those of a motivated "actor." When discussing the governor general's role as guardian of parliamentary democracy, I have chosen not to use the pejorative term "incapable" to describe Michaëlle Jean. The governor general did not and does not lack "capacity" to uphold the primacy of parliament. However, I argue that, in 2008, Jean was "ineffective" and/or "ill prepared" to guard a basic principle of Canadian parliamentary democracy. The final element of the theory, the suitability of the target, can be applied without restraint to the Canadian House of Commons. In keeping with the focus on "place" within RAT, parliament can be seen both as physical location and as concept, in which the Canadian people are represented through and by their elected Members of Parliament.

Using the above elements, I explore the main arguments surrounding the question of harm caused by prorogation, based on the consequences of this decision: a) the undermining of parliament's central role in Canadian governance; b) the reliance on nationalistic tensions between Quebec and the rest of Canada to delegitimize a political minority; c) and the apparent sanction of what appears to be a larger attempt to reform the constitution without debate, discussion, or even the minimal participation of the Canadian electorate.

\section{Stephen Harper as a Motivated Actor}

The 22nd Prime Minister of Canada, Stephen Harper won a minority government in the 2006 federal election. He was the first prime minister of the newly reconstituted Conservative Party formed from a merger of the Progressive Conservative and Canadian Alliance/Reform parties in 2003. Harper's Conservative Party won a stronger minority in the October 2008 federal election, despite a decrease in the popular vote. Behiels (2010) argues that Harper has successfully pursued a tactical political realignment of Canadian politics and positioned the Conservatives as the first right-wing political party in Canada capable of reconfiguring 
the role of the state at both the federal and provincial levels. In 2008, Harper's reputation as a tactician was seriously damaged when he turned an economic downturn into a national unity crisis. Even after he survived an all-party revolt that brought the country to the brink of a constitutional crisis, it is still unclear whether his actions constituted a pyrrhic victory.

Following the economic update delivered on 27 November 2008, the outcry in the House of Commons was immediate. Outside the House, negotiations began to defeat the Harper government (Topp 2009) and the Liberals announced they would use their opposition day to hold a confidence vote. If Harper's Conservative government had lost that vote, he would have had two standard options under our constitution. He could have held on to office and asked the governor general for a dissolution and another election, the second in two months. Alternatively, having lost the confidence of the House, he could have immediately resigned, in which case the governor general would have asked the leader of the opposition to try to form a government (Forsey 2010:4-5). Instead, on 4 December, Harper took the extraordinary step of asking the governor general to prorogue parliament to buy himself time.

To remain as prime minister, Stephen Harper took deliberate steps to undermine parliamentary democracy (Smith 2009). Of specific interest are three decisions he made leading up to his request that support his designation as a "motivated actor." The first can be connected to the broader trend connected to undermining the role and import of the Canadian parliament. In a clear and detailed analysis Lorraine Weinrib (2009) points to the actions taken before, during, and after prorogation that represent a clear pattern of parliamentary disregard. Weinrib (2009) describes Harper's failure to abide by the fixed-date election law passed by parliament, attempting senate reform without a debated constitutional amendment, and firing public servants to prevent them from appearing before parliamentary committees. The prime minister's decision to reschedule the confidence vote he was sure to lose and seek an adjournment of parliament through prorogation without clear constitutional precedent appeared even to conservative commentators as an example of the use of "any and every unsavory survival tactic" (Martin 2008). Through ingenious and clever scheduling, the prime minister was able to buy some time to develop a political narrative that would allow the Conservatives to stay in power.

The second decision embraced a narrative based on a long-standing effort to delegitimize the political minority represented by the Bloc Quebecois (BQ) (Levy 2009). In statements in the House of Commons Harper referred to the accord between the Liberals and NDP as undemocratic backroom dealing and claimed that the proposed coalition including the 
Quebec separatist BQ amounted to "a betrayal of the voters of this country, a betrayal of the best interests of our economy, and a betrayal of the best interests of our country" (Topp 2009). This theme continued as the Prime Minster erroneously alleged that three clearly visible Maple Leaf flags at the coalition's signing ceremony didn't exist, and railed against the "unpatriotic" coalition. Other conservatives like John Baird, JeanPierre Blackburn, and Jim Prentice equated support for the coalition with a "Separatist coup d'état" and threatened that "Conservatives would go over the head of Parliament and of the Governor-General"(Akin et al. 2008). These statements suggest a convenient memory loss over Harper's own attempts at parliamentary coalition building with the BQ while in opposition (O'Malley 2008), a willingness to stoke nationalistic tensions, and the complicated and often underestimated role of English/ French relations within our political culture.

Third, Mr. Harper's insistence that the government "will use all legal means to resist this undemocratic seizure of power" (Mercer 2008) suggests another departure from past practice. It became clear over the 8 days in November and December that, in his effort to hold on to power, he put forward an entirely new view of parliamentary democracy and the Canadian constitution. Dismissing his own party's failure to capture a majority in the 2008 election, he claimed that the coalition would overturn his minority party's right to power. Through Conservative radio and TV ads, Harper contended, "a leader whose party captured just $25 \%$ of the vote in the October 14 election doesn't have a legitimate mandate to govern" (Chase et al. 2008). The problem, as many have pointed out, is that Canadian democracy is not based on this sort of legitimacy. In Canada, it is parliament that receives its mandate from the Canadian people, and subsequently selects a government from among its ranks. A government's legitimacy is based on its ability to maintain the confidence of a majority of MPs in the House of Commons (Forsey 2010:28). If a government loses that confidence, the House has both the power and the duty to install a new government that could command that support.

Harper's view was based on the proposition that Canadians had elected him prime minister, despite the fact that no one outside his own riding could cast a single vote for him. While his local constituents elected him as their member of parliament, he was only one of the 308 who represent the Canadian electorate in the House of Commons. Harper was prime minister only because he was the leader of the party that had won the most seats, and, until then, had maintained the confidence of the House. In Harper's view, however, the elected members of parliament have no say in who will actually govern - a presidential/republican 
model which is completely different from the parliamentary form of government defined by our constitution (Forsey 1953).

\section{The Canadian Parliament as a Suitable Target}

The Parliament of Canada is the federal legislative branch located at Parliament Hill in the national capital region of Ottawa, Ontario. Formally, the body consists of the Canadian monarch (represented by the governor general), the Senate, and the House of Commons. Parliament is thus both a physical location and the embodiment of Canadian democracy. Central to parliament is the House of Commons, modeled on its British namesake, which plays the key role in Canadian democracy. It is the people's elected representatives in the House who introduce, debate, and pass legislation, and who choose from within their ranks what government they will support. To understand the parliament as a target of the harm that resulted from the 2008 decision on prorogation, it is useful to recall how this event furthered the reduced role for parliament, relied upon nationalistic tensions to delegitimize a political minority, and suggested a larger attempt to reform Canada's constitution.

First, as many have noted, the 2008 prorogation is another example of the repeated abuse of the confidence convention, one of most basic principles of responsible government (Levy 2009). This convention requires a legitimate government to hold the confidence of the House of Commons. Because these conventions have evolved through history and remained uncodified, the scope of this convention is largely not understood by Canadians (Russell 2008). A number of related challenges have also emerged. In Canada, as in other parliamentary systems, there has been an effort to bypass parliament and centralize prime ministerial power. Tony Blair was the most recent prime minister to bypass both the cabinet and the British Parliament at Westminster when setting British policy during his time in power. Widely criticized for making decisions alone or with a small group of nonelected advisers, he was often referred to as "President Blair" (Foley 2000). Since his election in 2006, Harper has pursued a similar strategy, successfully consolidating his power under a model of unitary executive at odds with parliamentary traditions in Canada (Weinrib 2009).

Second, in addition to efforts to reduce the role of parliament during December 2008, the prime minister also attempted to influence the governor general by harnessing public opinion against the $\mathrm{BQ}$. The Prime Minister's Office (PMO) organized a protest at the governor general's residence and Conservative staffers in Ottawa were given the day off to stand and wave signs reading, "The Bloc Sucks" and "Stop the Coup" (Mercer 2008). Other Conservative MPs like Finance Minister Jim Fla- 
herty stoked the fires of populist anger by suggesting that any coalition supported by the Bloc was "a deal with the devil" (Whittington et al. 2008). The examples of anti-Quebec coverage in English Canada during the 8 day parliamentary crisis were a reminder that the phenomenon of Francophobia in English Canada remains. As Fraser (1998) suggests, many across the country believe bilingualism is a conspiracy against English Canadians to guarantee jobs for Quebecers. This Francophobic jingoism present in our political culture (Potvin 2000) indicates that true national unity in Canada remains elusive. Linguistic, cultural, and political differences between English and French Canada remain vast as each group conceives of the country in different ways.

While the laudable broader goals of multicultural tolerance have resulted in an uneasy truce between Quebec and the rest of Canada, these differences have been manipulated for political advantage on many occasions. Some have suggested the perceived illegitimacy of the coalition can be explained by the lack of Western representation within it (Skogstad 2009). However, it should be recalled that the notion that the BQ represented an "illegitimate" political minority echoed arguments made in 1994. At that time the Reform Party, the precursor to the current Conservative party, argued that the BQ should be denied the role of Official Opposition, despite the fact it had garnered the second largest number of seats in the House of Commons (Levy 2009:27). This divisive approach to English-French relations reappeared in 1997 when Reform ran what were described as "race-hate ads" (Winsor 1997) that questioned the patriotism of politicians born in Quebec.

Third, the suitability of parliament as a site for the harm that occurred through prorogation should also be seen as a result of a majority of Canadians not understanding how their system of governance works (Levy 2009). The widespread misunderstanding of our parliamentary system has contributed to a dangerous undermining of democracy itself, and it appears to be present throughout Canadian society (Clarkson 2009; Forsey 2009). In a speech last fall at Queen's University, former Prime Minister John Turner said that it will be difficult in the future to attract good, new people into Canadian politics if the power and prestige of the House continues to erode. "Democracy doesn't happen by accident," he said. "In this country we are taking it for granted. We're not paying attention" (Foot 2009).

This lack of attention is perhaps best demonstrated by considering the decline of political participation on the part of the Canadian electorate. Historically, Canada has enjoyed relatively high levels of voter participation in federal elections. However, since 1988, when over $75 \%$ of Canadians voted, the percentage of Canadians voting has declined 
Table 1 - Canada Voter Turnout 1988-2008 ${ }^{1}$

$\begin{array}{cc}\text { Year } & \text { Voter Turnout \% } \\ 1988 & 75.3 \\ 1992 & 71.8 \\ 1993 & 69.6 \\ 1997 & 67.0 \\ 2000 & 61.2 \\ 2004 & 60.9 \\ 2006 & 64.7 \\ 2008 & 58.8\end{array}$

1. Compiled from Elections Canada data available at: http:// www.elections.ca/content.asp?section=pas\&document $=$ tur nout\&lang $=\mathrm{e}$

significantly. As Table 1 demonstrates, in 2004 only $60.5 \%$ of eligible Canadians voted and while this trend was moderately reversed in 2006 it reached historic lows in 2008 when a mere $58.8 \%$ of Canadians cast ballots.

While optimists might see this as an indication that voters are pleased with past leadership, the decline of participation by citizens in advanced democracies is more often met with concern. Chief of these concerns is connected to voter turnout (Blais 2006; Jackman 1987; Powell 1986). In Canada, socioeconomic status, regional variations, and demographic differences have been shown to influence voting patterns (Bakvis 1991). An emergent concern is voter apathy in the 18-35 year-old demographic. A number of explanations have been posited for this political disengagement. Some argue that the inherent undemocratic nature of "first past the post" electoral systems has undermined interest in elections (Pilon 2007). Others argue, drawing on US studies, that youth do not believe their vote matters or can make a difference (Horwitt 1999; Teixeira 1992). One theory is that this is a manifestation of social disorganization as meaningful person-to-person social interactions and participation in community-based activities become more rare (Putnam 2000).

Suggesting that parliament and, by extension, the Canadian electorate served as a suitable target conflates a broad collection of voices and views. The lack of even a basic understanding of our system of governance allowed prime ministerial misrepresentations to be taken as fact. While more recent events have challenged the notion of the electorate as complacent, in 2008, the population was unengaged, ill informed, and unaware. Without reasoned discourse by informed experts, the Canadian public was treated to spectacle, not facts. Canadians were ill prepared to challenge the new and totally untested proposal, pushed by what by Don Newman called "the fantastic Tory spin machine" (Klein 2009), to change the way democracy operates. In 2008, neither Opposition MPs 
nor the Canadian public appreciated the dangers of this proposal, nor was the governor general prepared to guard their constitutional interests.

\section{The Governor General as Ineffective Guardian}

Michaëlle Jean was born in Haiti and came to Canada in 1968. Raised in a medium sized town in Southwestern Quebec, she received a number of university degrees in languages and literature, and later worked as a journalist and broadcaster for Radio Canada and the Canadian Broadcasting Corporation (CBC). She was appointed as Governor General in 2005 and served until 2010. Much loved in Canada to this day, she prioritized respect for Canada's military and the dignity of aboriginal traditions around community and food. She has more rarely been criticized for her role in the 2008 prorogation. As a basis for any critique, it is useful to consider the impact of her decision on the primacy of parliament, nationalistic "narrative," and longer term constitutional debates and precedents.

On the first point, there can be no doubt that the decision to prorogue Parliament usurped parliamentary power by canceling a confidence vote in the House and failing to safeguard democratic legitimacy (LeClair and Gaudreault-DesBiens 2009). This was not widely seen as problematic because few Canadians in 2008 appreciated the governor general's explicit constitutional duties. Chief among these is the importance of the duty to uphold principles of responsible government and the will of parliament. Nevertheless, there remains a view that the Crown must balance these duties with political considerations about the well being of the country (Russell and Sossin 2009). Without a transparent means to investigate and assess how governor generals are to balance these competing functions (Sossin and Dodek 2009), there is a risk that the defender of Canada's parliamentary democracy may undermine constitutional principles to accommodate personal or political calculations. On one view, this is exactly what happened in 2008, when instead of holding the government accountable (Heard 2009), she became the "Vice-Regal of Irresponsible Government.”

There is no historical precedent for a Canadian governor general refusing to grant prorogation and the circumstances of Harper's December 2008 request were themselves unprecedented. However, relying upon the absence of precedent to make a decision is problematic when the request itself is at odds with core principles of responsible government. As Heard (2009) points out, Harper led a minority government that was under serious scrutiny in the House mere months following two elections that had returned a House where the majority of members occupied opposition benches. In these circumstances, any vote of confidence 
becomes crucial. Since the 2008 prorogation, a variety of replies to this confidence question have been offered. One early view was that while Harper was likely to lose the confidence of parliament in the vote scheduled for a few days later, that vote had not yet taken place. Indeed, a few weeks earlier, the House had indicated its confidence in the government by voting with the government on the throne speech (Miller 2009:104). Accordingly, the governor general was obliged to act on the advice of the prime minister (McWhinney 2005). This has more recently been challenged.

Other constitutional scholars hold that while the government had won its vote of confidence on the speech from the throne, this did not establish an unquestionable right to govern. Indeed the government's motion on the address in reply was successfully "amended with very important caveats" (Heard 2009:6), leaving the question of confidence in doubt. The most recent analysis by noted expert Professor Peter Hogg (2010) accepts this view. He argues that in 2008 the governor general did not need to accept the advice tendered by Harper, as it appeared he was about to lose to confidence of the House. When the confidence of the House is in doubt, the governor general can rely upon a "personal prerogative" to decide whether or not to accept any advice that is tendered. For Hogg (2010) this decision may involve political calculation. Indeed in 2008 , there were a number of political questions to be considered. One of the most complex was how to manage the suggestion that a coalition government would represent a "separatist coup."

On this second point, the nationalistic narrative, established by the government, that a coalition would represent a coup by the Quebec separatists placed the governor general in a difficult personal dilemma. Jean's husband, Jean-Daniel Lafond, was well-known as a documentary filmmaker with an interest in, if not an affiliation with, the Quebec independence movement. In fact, shortly after being named governor general in 2005, Jean was forced to issue a statement denying she or her husband had links to the separatist movement. At that time, as leader of the opposition, Stephen Harper responded by suggesting there were still questions about her loyalty to Canada. ${ }^{3}$ Caught between competing views of her obligations, Jean chose the prime minister over the people as represented by the parliament.

The governor general's personal dilemma was magnified by the concern that Jean faced a motivated prime minister who was unlikely to ac-

3. In August 2005, then governor general designate Michäelle Jean spoke out against allegations that she and her husband harboured separatist sympathies. Retrieved 31 December 2009 from CTV http://www.ctv.ca/servlet/ArticleNews/story/ CTVNews/20050817 jean comments 050816/?hub=TopStories. 
cept a refusal of his request. The general expectation is that a prime minister who is refused by the governor general will resign, but in this case it appeared unlikely (Heard 2009). Some commentators have suggested had Harper been refused, he would have continued to fight by attacking the governor general, and provoking a true constitutional crisis, pitting East against West and Québec against the rest of the country (Desserud 2009; Franks 2009). We now know he would have appealed to the Queen — another astonishing proposition, which as Forsey (1990) points out, would surely have been met with a polite, but firm, rebuff. Such actions by the prime minister would have plunged the country even further into chaotic political uncertainty. While charges of constitutional crisis raise the level of hyperbole, the vitriol on display provided disturbing evidence of a deeply divided country (Martin 2010).

In the end, Canada's multicultural tolerance works less well in practice than on paper. An especially grievous harm since 2008 has been the implicit assumption that Canadians with a different political outlook and/or language do not deserve the same constitutional right to fully participate in the affairs of the House of Commons and the country. The lack of consensus about the roles of the prime minister, the governor general, and parliament creates an environment in which the governor general cannot be counted on as a capable guardian of the Constitution in defence of responsible government. Without a robust role for the governor general to defend the primacy of parliament, our system of government is vulnerable to a motivated political actor unencumbered by a fidelity to the Canadian constitution or our governing traditions. This is problematic because as Eugene Forsey (1967) stated in a rather prescient phrase:

If a Prime Minister tries to turn Parliamentary responsible government into unparliamentary irresponsible government, only the Crown can stop him; only the Crown can keep government responsible to Parliament and Parliament to the people. (Forsey 1967:30)

Third and perhaps most worrying, is that the decision to prorogue parliament was made just as the prime minister was attempting to popularize the proposition that our system of governance is based on popular and direct elections and not representative democracy. First presented by Stephen Harper and later clarified by Tom Flanagan (2009), this new approach to Canadian governance is based on the notion that our antiquated system of responsible government is less democratic than other alternatives. To address this limitation Flanagan (2009) suggests that the people of Canada must directly elect a Canadian prime minister, and that any coalition government must gain a mandate through an election campaign (see Simpson [2009] on this point). While some suggest this view 
ought to be more widely considered (Potter 2009), the conceptual and practical limitations of adopting it seem insurmountable. Such a proposal would require the transformation of our existing parliamentary system into a republican/presidential model and undermine the consensus-based realities of minority governments (Russell 2008).

For Andrew Heard (2009), at issue is that overturning principles of responsible government by allowing the prime minister to run from parliament sets a terrible constitutional precedent. Rather than leadership based on the confidence of the House, proroguing parliament would validate prime ministerial avoidance and undermine representative democracy. For Heard (2009: 60), "the events of December 2008 now provide a clear precedent for any future prime minister to demand that Parliament be suspended whenever he or she feels threatened with defeat." This might include the threat of a nonconfidence vote, to break the will of the opposition, or to limit the role of MPs whenever they pursue questions that in the opinion of future prime ministers endanger their political leadership. While the power of this precedent going forward has been questioned (Forsey 2009; Hogg 2010), by acquiescing to Harper's request, the governor general did appear to sanction his disregard for parliament and by extension the Canadian people. This decision may have longer term implications if Jean's failure to protect responsible government in 2008 is attributed to the office of governor general.

\section{Discussion: Routine Activities Theory and Lessons Learned}

The utility of RAT is that it offers a model to understand political harms by considering the intersection of three different but related elements (Akers and Sellers 2004). Without any one element, according to the RAT, harm is less likely to occur. What if the prime minister had been unwilling to exploit nationalistic tensions or engage in constitutional misrepresentation? What if the Canadian public had seen the Conservative media blitz as a cynical attempt to avoid parliamentary democracy by invoking a "faux" populist agenda (Smith 2009)? What if the governor general had required the prime minister to demonstrate he had the confidence of the House before considering prorogation? I would suggest that lacking just one of these elements would have created a very different outcome to the 2008 crisis. By focusing analysis on the relationships between these elements, it may also be possible to chart a course to correct what is today seen as a dangerous constitutional outcome (Heard 2009).

Challenging the past actions of the prime minister may seem at this late stage to be inconsequential, although Harper may still pay a political price for his actions. Some have suggested that the decision to 
prorogue served to humble the prime minister, who would as a result be more accountable to parliament (Cameron 2009), but that prediction appeared naïve barely a year after the event. If anything, Harper took from this episode implicit approval for the next time he requested prorogation. At the end of 2009 , he used the same mechanism to shutter politically inconvenient questions about Canadian foreign policy and the treatment of Afghan detainees, meanwhile appointing a number of Conservative Senators to bolster his position once the new parliamentary session began. Once motivated actors accept that their actions constitute a rational means to maximize their own benefit, changing the situation to reduce the opportunity for future harms will likely be more successful than changing their behaviour (Miller et al. 2007:104). Within the theoretical framework, one can either strengthen the target or augment the capacity of the guardian.

The question of how to strengthen parliament and what to do about the pervasive constitutional illiteracy of Canada's electorate is complex. This was not "a crisis made in a day," and efforts to strengthen parliament require sustained political pressure from MPs who have played a less central role in the governance of the country (Levy 2009). One suggestion, in 2008, was to require the prime minster to get the permission of the house before requesting prorogation. Such a resolution would not only preserve the vital reserve power of the governor general to accept or refuse prorogation or dissolution in certain exceptional situations, it would also reenforce parliament's central role in our system of government. Ensuring the decision to shut down parliament is made democratically, would prevent transgressions like the recent actions of Prime Minister Harper.

This is a useful first step, but we may need a more in depth "national conversation" about what kind of Canada we want. There are many good ideas and considerations (Russell 2009; Smith 2007) to bring to the table. The lack of general agreement over existing Canadian conventions is based more on lack of knowledge and understanding than on informed and considered debate. The level of confusion among citizens, journalists, and even noted academics appears too high for such a debate - a warning sign to educators about the state of Canadian civic education. If Canadians are ever to establish a firm basis for their identity and safeguard their democracy, they must achieve a far greater understanding of Canada's history and system of government. This may be difficult when over half of the ten Canadian provinces currently do not include Canadian history as a mandatory requirement of school curriculum (Cohen 2007). Clearly, without common understanding about our governing principles and traditions, the potential for an informed citizenry to par- 
ticipate in the democratic process is reduced. On one view every electorate gets the government they deserve. Yet unless they are properly educated about Canada's system of responsible government and reasonably informed about the nature of debates, constitutional or otherwise, the myths of democracy may come to substitute for the complex reality (Forsey 2009).

While it was clear that the Canadian public in general was ignorant about Canada's constitutional framework and system of governance, few polls focused on this lack of understanding. ${ }^{4}$ In an increasingly corporatized Canadian media environment, the coverage of these crucial events was uneven at best, and partisan at worst. There was little coverage of the fact that the protests outside the governor general's residence had been orchestrated by the Prime Minister's Office, and no one noted the potential personal conflict of interest that the "separatist takeover" narrative implied for the governor general. Without more study on how the media chose to present this episode, it may be unfair to simply blame the Canadian public, as some have done (Coyne 2009). Reengaging and informing citizens about how their democracy is designed to work is clearly a longer term project involving the media, academics, and politicians as well as the general public.

Contrary to suggestions in the popular press that the governor general had no choice but to accede to Harper's wishes (Topp 2009), it is clear that the decision to prorogue in 2008 was at her discretion (Russell and Sossin 2009). Indeed, as Eugene Forsey (1943) pointed out, the reserve power of the Crown is included in the Canadian Constitution precisely to protect fundamental democratic rights in such situations, preventing an autocratic government from forcing the opposition to acquiesce by dispensing with any parliament it does not like (Forsey 1967). Rather than simply being a rubber stamp for the cabinet in office, the governor general, in her role as guardian, must on rare occasions use her reserve power to refuse requests or advice from a government when the confidence of the House is in question (Forsey 1990; Hogg 2010). One reason for the lack of understanding of this role is that successive majority governments in Canada have allowed the question of confidence to remain invisible - the government's majority virtually ensured the

4. The opinion polls from that time are hardly conclusive. Despite the punditry more Canadians thought the Conservatives had lost the right to govern than thought they should remain (Angus Reid Strategies 2008). In addition Canadians were evenly split on whether or not they supported prorogation (Ekos Associates 2008). The real problem was that the polls focused on the personal popularity of leaders, which is irrelevant given that once an election has occurred in a parliamentary democracy, only the support of MPs in the House matters. Another issue based on the questions asked in the polls was the apparent presumption that respondents understood not only the immediate outcome of the prorogation request, but the larger constitutional implications as well. 
confidence of the House. The fragility of minority governments, though widely understood among the political class, appears to most people to be a mere procedural matter; the threat of defeat on a confidence motion is just one of the games they play in Ottawa. Had the public been better informed in 2008, Harper's request to prorogue parliament would have been more readily seen as the revolutionary act it was.

It is hard to argue that the governor general defended the Canadian constitution in 2008. Allowing a prime minster of a minority government to avoid a nonconfidence vote by proroguing parliament strains the principles of responsible government. By allowing Harper to delay a vote that he was likely to lose, and suspending the elected parliament before it could decide the government's fate, the governor general denied parliament its essential constitutional role of holding the government accountable and, if necessary, replacing it with another (Forsey 2009; Heard 2009). In the current era of minority governments and fractured political discourse, Canadians need to rethink their concept of the role of the governor general as mainly ceremonial (Miller, 2009). A more functional role needs to be envisaged for the person responsible for overseeing transitions from one government to the next. This will require a better understanding of and fidelity to the conventions of responsible government, including a strengthened acknowledgement of the constitutional role of the governor general in defending parliament against the potential excesses of future prime ministers (Forsey 1943).

It will also require more thought about what - if any - political role the governor general should play, as opposed to the strictly constitutional function. Some of the suggestions made since the 2008 decision offer new reasons for concern that a more active governor general might overstep the legitimate constitutional role (Forsey 1990). This might be mitigated through appointment processes with greater transparency and accountability (Miller 2009), although, as Stilborn (2009) points out there is no convention about updating conventions. With this in mind, it may be useful to look to other commonwealth countries such as Australia and New Zealand (Russell 2009). One approach would be to amend the constitution to clearly codify the role of the Crown in Canada. As a formal addition to the written constitution, this would subject the governor general's decisions to judicial review and outline in legal terms what historically has been unwritten convention. Whatever the merits of such entrenchment might be, it would be fraught with difficulties both practically and constitutionally, and extremely costly politically (Forsey 1990; Russell 2009).

Another approach based on the analysis in this paper considers a process to ensure a deeper understanding of existing conventions. Instead of 
engaging in complex constitutional negotiations like its neighbour Australia, New Zealand pursued a less formal approach. Based on the concerns about the potential for minority government mischief by successive governments, New Zealanders embarked on a process in the 1970s that involved a clear elucidation and compilation of cabinet procedures and constitutional developments (Russell 2009). While not forever set in stone, New Zealand's cabinet manual provides the history, justification, and relevant precedents to guide governments in new political situations. Through an explicit presentation of the requirements of constitutional conventions and the roles and responsibilities of key actors, the manual has been updated from time to time to reflect established changes.

The advantage of course is that the consensus view is set out in an authoritative and accessible way and represents the current state of the constitutional and administrative practice in that country. This practical approach is a useful model to emulate. By developing an online, user friendly, and searchable Canadian version of New Zealand's cabinet manual, Canada could realize many of the benefits of a constitutional amendment, without some of the challenges inherent within our unwieldy and increasingly divided federal system. While the creation of such a cabinet manual could not address all the challenges faced by minority governments, it could combine efforts to educate and engage the public and offer clear guidance should future constitutional crises return to Canada (Stilborn 2009).

If the problem is a lack of consensus about the conventions and mechanisms of parliamentary responsible government, how could this manual be compiled? One suggestion is a royal commission appointed to independently consider the applicable law, convention, and customary understandings that guide our parliamentary governmental system (Smith 2007:140). Through it, a broader consensus could emerge, and Canadians could compare the system that has served us for a centuryand-a-half with the untested, unjustified, and unknown attempt at hybridization offered by Flanagan and Harper. If Canadians decide they really want a new approach to Canada's constitution, let's be sure it is achieved through a process that is legitimate, accessible, and transparent. While more study may be needed about how best to adopt the New Zealand approach, the cabinet manual provides an important example of how to ensure transparency and accountability on questions of such importance (Russell 2009). Few would argue against the notion that Canadians and the governor general should be better prepared should such a situation arise again. 


\section{Theoretical Limitations, Peer Reviews, and Personal Discretion}

A number of limitations or concerns may be raised concerning the analysis presented in this paper. Cross application of theories from other disciplines often results in the tendency to pick and choose elements of theories that one likes, while disregarding the others (Heidt 2003; Wheeldon 2009). In the rush to apply theories from one discipline to another, conflicting base assumptions may be ignored (Akers 1989; Hirschi 1989). The best way to mitigate this potential is to acknowledge the limitations inherent in the endeavour (Heidt 2003). While RAT is adaptable to other sorts of social harm, I am not aware of any attempts to apply the theory to these unique political events in Canada or elsewhere. This paper has presented prorogation as the culmination of actions designed to undermine parliamentary supremacy - all too common in Canada - and offered one means to explore this decision.

Another challenge was how to connect the major actors in this crisis with the major elements of the theory. Harper can be seen as a rational actor seeking to maximize his own interests and parliament, and by extension the Canadian public, can be seen as a suitable target. One problem, however, is that based on the construction of the theory, the governor general could be seen as more than a guardian. In fact, given the many roles the position occupies in Canada, it could be argued that based on RAT the governor general could be seen as an actor, or a coconspirator with Harper. Alternatively, as a part of parliament, the governor general might also be seen as a target if the precedent set by the 2008 prorogation reduces the application of her reserve powers in future. This paper has taken the view that while the special role of the Crown allows the governor general to play a number of roles in Canada, it is more appropriate to describe her role here as one connected to an inadequate and/or ill prepared guardian. While more analysis is needed to assess the ways in which Jean may have been manipulated in 2008, the personal and politically awkward position she was placed in by the prime minister must not be ignored. At the very least, as this has paper has argued, there is a need for more discussion and debate about the future role of governor general in Canada.

Other important questions have been raised. While this paper has benefitted from a number of reviews, edits, phone calls, and even arguments, two limitations have emerged from my efforts to publish this paper in other Canadian peer reviewed journals. They are useful because they highlight what I consider the main challenge for multidisciplinary social scientists and a major limitation in the existent world of field specific journals and insular programs of study. The first question is con- 
nected to the suitability of applying a sociological theory like RAT to the rarefied field of political science. One reviewer, instead of accepting the limitations inherent in any cross application of theories, suggested the paper was unconvincing because defining prorogation as a "harm" would represent a backdoor attempt to criminalize politics as a whole. This reviewer argues that the political system in Canada actually relies upon misrepresentation, the exercise of political manipulation, and the relative lack of information or knowledge among the public. If this is so, it would follow that one cannot label the actions of a prime minister "harmful" without indicting much of the political system as well.

Another reviewer suggests that one cannot discuss whether or not prorogation should have occurred without relying upon sociological definitions of harm. Implicit in this critique is that only political scientists using their own theories ought to engage in explorations of this kind. The problem is, that while some in the political scientist community agree that basic principles of responsible government are contested, they are unwilling to even contemplate how the events of 2008 might be challenged. It is already questionable to excuse a constitutional decision on the basis of a subsequent political outcome (Cameron 2009), but it is frankly intellectually dishonest to deny that defying long-established constitutional principles might be negative. I encourage the next generation of political science students to explore other rational choice theories in economics, political science, and even sociology to provide an alternative account to explain how the 2008 prorogation was used for the subordination of principles of responsible government to short-term political convenience. Let the best explanation win!

Additional reviewers pursued a line of critique that highlights another problematic assumption among some law and society scholars. One of them adheres to a rather strict view of what can or cannot be explored using RAT and a rather limited view of how the elements of a theory can interact. Their views do not accord with my own exchanges with Marcus Felson, co-author of RAT, and fail to consider other more flexible approaches to theoretical explorations. This concern is based on the doubt that any meaningful consensus exists around notions of "accountability," "discretion," and "transparency" in Canada. Since responsible government is a contested concept, on this view, by attempting to show that is has been harmed, I assume what I am trying to prove.

This is the sort of critique I have come across in the past and have attempted to address elsewhere (Wheeldon and Heidt 2007). While efforts to redefine and reconsider past assumptions, and democratize questions of justice, law, and society must be commended, the unwillingness to debate contested political questions because it presumes that one defin- 
itive answer is possible contributes to the current malaise in the social sciences. It is connected to what might be called the "critique without construction" school within a number of academic disciplines. Thankfully, a new generation is emerging for whom these concerns seem old fashioned and quaint. Of course these concepts are contested - that is the whole point. To engage in pragmatic scholarship, though, one must be able attempt to locate a convincing set of definitions, facts, and arguments based on credible academic scholarship while acknowledging that your view may be wrong. In my view, it is far more dangerous to say that basic constitutional principles have no basis, no roots, and no purpose than to acknowledge that the mechanisms for implementing those principles can also be used for Machiavellian advantage.

Together these two critiques demonstrate exactly why it is necessary to reengage and reinvigorate multidisciplinary analyses. While this may be done in a variety of ways, to discount the cross application of a theory from one discipline to another on mere technicalities is beneath the imagination of considered scholars. The application of RAT as presented in this paper must succeed or fail based on its ability to offer a more complete view of events than existing theoretical treatments. As no others have been offered, it might be said to have some distinct advantages. The main benefit is that it offers a clear view into how responsible government, as traditionally defined, has been undermined. As Slattery (2009) has discussed in great detail, while the Supreme Court has noted that constitutional conventions are only effective as rules of proper conduct when the relevant actors accept them, their importance as part of Canada's constitution should not be overlooked. ${ }^{5}$ The analysis of the 2008 prorogation in this paper may suggest the practical problems that arise when one actor refuses to be bound by traditional understandings of parliamentary democracy.

Finally, despite the persistent and perceptive critiques of the 2008 prorogation on political, social, and constitutional grounds (Heard 2009, Miller 2009, Smith 2009, Weinrib 2009), there remains a view that "ultimately, the system worked" (Cameron 2009:189) and, that despite reservations, prorogation was an acceptable outcome. This is based on the view that without clear constitutional precedent, the governor general had to be concerned with the risk of a political crisis at a time of great economic uncertainty (Russell and Sossin 2009). Few doubt that the governor general faced a difficult decision and that as "the ultimate protector of the constitutional order" (Slattery 2009:88) the office holder

5. See Slattery's (2009) useful discussion on both Reference re a Resolution to amend the Constitution, [1981] 1 S.C.R. 753 (Patriation Reference), and Reference re Succession of Quebec, [1998] 2 S.C.R. 217 in Russell and Sossin (2009). 
has a duty that must be discharged with considerable discretion. At issue is the nature of this discretion.

According to Peter Hogg, the "wise" exercise of this discretion involves a number of political calculations. In 2008, these included the undesirability of another election so soon, the perceived weakness of the Liberal leader, the need for BQ support, and what he suggests was the fragility of the coalition, organized in "haste and anger" (Hogg 2010:200-201). As one of Ms. Jean's advisors in 2008 and a noted constitutional authority, Professor Hogg's analysis deserves careful scrutiny. One observation is that he uses largely normative judgments in presenting the constitutional options available to the governor general (Delacourt 2010). In addition, his justification of an overtly political role for the governor general appears to go beyond the traditional understanding of the Crown's "reserve powers" to refuse the advice of a prime minister who does not have the confidence of the House. Hogg (2010) suggests that these powers provide the governor general with "personal discretion" not only to determine whether the prime minister has the confidence of the House, but also to assess the political desirability of any alternative government that might be formed. This appears not to be limited to an assessment about whether a proposed alternative government could hold the confidence of the House, but whether this alternative and its leadership would be politically appropriate. ${ }^{6}$

Hogg (2010) provides no other authority for this sui generis power, and does not examine situations in which this personal prerogative or discretion could be hijacked, manipulated, or otherwise influenced. If he is correct, then the governor general in Canada has a personal prerogative to intervene in the business of parliament in ways that are totally unique in the commonwealth (Foot 2010). ${ }^{7}$ Other commonwealth countries may recognize more clearly the need that governors general be and be seen as — impartial and above partisan politics (Forsey 2009). Without that recognition, it may be impossible to separate the constitutional duty to preserve responsible government from the political preferences of the person who occupies the office of the governor general, or the predilections of their advisers. As this paper has detailed, the exercise of political leverage by a motivated prime minister may have profound constitutional consequences when the governor general's powers are not

6. This is a view that has no corollary in other commonwealth countries. For example, in New Zealand "reserve powers" include no discussion of personal prerogatives. Retrieved 1 Nov 2010 from: http://www.gg.govt.nz/role/powers.htm.

7. Foot argues no other English-speaking nation with a system of government like ours has ever had its parliament prorogued in modern times, so that its ruling party could avoid a vote of confidence. 
limited to ensuring Canada always has a government that holds the confidence of the House.

Perhaps the willingness of some noted Canadian scholars to accept the 2008 prorogation is attributable to something beyond the constitutional analysis offered in this paper. For many, there was and remains a complex issue about how best to accommodate a federal political party whose rhetoric suggests a sole focus on the nationalistic interests of Quebec and Quebecers. There could be entirely legitimate concerns about the potential influence of an avowedly separatist political party working in partnership with the national government - whether that government was a single party or a coalition. One does not need to be "anti-Quebec" or "Francophobic" to raise serious questions about such influence. These political concerns, while still subject to the most rigorous debate in our democratic system, must not be used to override the tried and true democratic mechanisms - notably around confidence - that have been integrated into our Constitution and are maintained in parliament. The notion that the governor general or her advisors can simply substitute their own political or personal judgment about one party or leader over another is a betrayal of the democratic system they are sworn to protect. If we cannot be sure those charged to protect our system of government respect its underlying principles, the credibility of the system itself will be further eroded, and its ability to function destroyed. The most important duty of the governor general is to ensure that parliament is permitted to do its job.

There is some indication that Canada's newest governor general David Johnston does not accept the theory of constitutional discretion exercised in 2008. While it may be too soon to say with certainty, Johnston appears to be distancing himself from the overtly political view of the governor general's role. He has suggested he is not a "political referee" (Scoffield 2010) and that he hopes to leave the office "better than when [he] found it" (Taber 2010). Rehabilitating the constitutional role of the governor general will involve discussion and deliberation well beyond Sussex Drive, and among more people than those advising the occupant of Rideau Hall. If not, post hoc analysis may continue to justify outcomes that undermine constitutional principles whenever they conflict with political considerations (Miller 2009:7).

Integral in the future assessment of the value of the proposed model in this paper are more attempts, examples, and analysis that test the application of RAT using other political events. Perhaps more scholars will consider the ways in which theories and approaches from their disciplines can be applied to constitutional matters. Clearly political scientists would benefit from more nuanced views about the role of power in pol- 
itics. Without future explorations, however, it is difficult to say whether or not this is an appropriate use of this sort of framework. The utility of this application of the theory need not be decided solely on analytical grounds. A useful theory provides testable propositions that can use empirical and/or analytical approaches to assess a theory's applicability. Those interested in political criminology might consider to what extent this theory can be applied to other constitutional questions. Can pattern analysis offer a means to establish that a pattern of political harm exists? Can harm be operationalized in the ways suggested in this paper? Can this approach be used to understand the 2009 prorogation?

While a detailed analysis of the above questions is beyond the immediate purview of this paper, there are some interesting similarities and some important differences between the 2008 and 2009 prorogations. In 2008 at issue was the way prorogation undermined the confidence convention, stoked nationalistic tensions, and appeared to sanction constitutional inversion without any democratic process. While the politically unpopular 2009 prorogation was actually more legitimate in strictly constitutional terms than the prorogation of 2008, Harper's request was once again tactical. In 2009, the harms were again first and foremost against the primacy of parliament and the right of MPs to view documents related to the Afghan detainee issue. Once again it was the prime minister who sought to avoid parliamentary accountability. In this case however, the confidence of the House was not in question and the governor general was obliged to grant his request. Instead it fell to the Speaker of the House Peter Milliken to guard the primacy of parliament regarding the documents.

\section{Conclusion}

The 2008 decision by the governor general to grant Prime Minister Harper's request for prorogation appeared to sanction the subversive constitutional proposition that a government can simply suspend parliament when faced with a potential nonconfidence vote. This is not a mere procedural matter; it is an affront to Canadian democracy, history, and system of governance. When the governor general acts as a mere rubber stamp, the prime minister's powers are elevated and parliament becomes irrelevant except for public show. If prorogation can be relied upon as a matter of course, nonconfidence votes can be delayed indefinitely. Minority governments will not be compelled to cooperate with opposition parties who represent many more Canadians, nor must they demonstrate that they retain the confidence of the House. Based on the analysis in this 
paper, the grand departure from Canada's constitutional conventions in 2008 came at a high price.

It seems unlikely the arguments that underpinned the 2008 prorogation will be relied upon in future. By agreeing to delay a crucial scheduled confidence vote, the governor general up-ended core principles of responsible government, furthering a pattern of government disregard of parliament that has become all too common. In this case, prorogation also had the shameful effect of delegitimizing a political minority. This paper has argued that together these events represented a harm that can usefully be analyzed through the confluence of factors suggested by RAT.

While more work is needed to test the theory and the model of political harm it assumes, it is not enough to presume that only political scientists can evaluate power. Nor is it acceptable to suggest that the principles upon which this country's democracy is based are mere social constructions devoid of meaning, logic, or legal force. As events have shown, without a strong guardian of responsible government, parliament and a constitutionally illiterate population are no match for a political actor who is motivated to hold on to power.

However, there are reasons to remain optimistic. Ironically, while the second prorogation in 2009 was not dubious in strictly constitutional terms, it did highlight what many saw as yet another example of the routine contempt the ruling Conservatives held for parliament. In the space of weeks, hundreds of thousands of Canadians had joined an online antiprorogation movement, wrote letters, organized workshops and teach-ins, and engaged in a coast to coast discussion of prorogation and the increasingly undemocratic nature of Stephen Harper's Canada. This movement served as the largest political social media moment in Canada to date, and through it Canadians appeared more educated and engaged.

So what should have been done in 2008 ? To conform to the centuriesold principle that the prime minister must always retain the confidence of the House, the governor general should have required that Mr. Harper face parliament before she considered his request. If the vote had been allowed to take place and the government survived, a subsequent prorogation would have been routine once the session had finished its business. If the government had not survived the vote, the governor general would have been obliged to call on the Leader of the Opposition to form a government, since the confidence of the newly elected House was assured by the coalition agreement.

Whether or not the resulting coalition government would have been popular is completely irrelevant to the rightness or wrongness of the governor general's decision. Neither should the possible risk of further 
disruptive actions by Harper following his defeat, or the economic insecurity that might have resulted be used to absolve those who perpetrated this subversion. These are all political questions that must be resolved by our elected representatives in parliament, where the legitimate power to govern Canada resides.

Undoing the damage done by the 2008 decision will require the mobilization of concerned citizens, diligent reporting by the media, and responsible action by a historically and constitutionally informed political leadership. There is evidence that these issues are likely to reappear in the years to come as Canada's fractured polity requires more and more cooperation among parties and within future parliaments. We will need a strong governor general to ensure parliament's role is respected. The ignorance of the electorate in 2008 should remind those of us interested in governance that informed dialogue, debate, and deliberation are necessary parts of democracy. Transparency and accountability on questions such as these is a matter of vital national importance.

While defining and outlining the roles and responsibilities of key actors in our system of governance will require political leadership, there may be many benefits if it is tied to a larger democratic reform package. Few would doubt the need to educate Canadians, illuminate and validate core constitutional principles, and ensure the means to prevent future harms against the people's parliament.

\section{REFERENCES}

Akers, Ronald L. 1989. A social behaviorist's perspective on integration of theories of crime and deviance. Pp. 179-195 in Steven F. Messner, Marvin D. Krohn, Allen E. Liska, eds., Theoretical Integration in the Study of Deviance and Crime: Problems and Prospects. Albany, NY: State University of New York Press.

Akers, Ronald and Christine Sellers. 2004. Criminological Theories: Introduction, Evaluation, and Application. Los Angeles, CA: Roxbury Publishing Company.

Akin, David, Mike de Souza, Andrew Mayeda, and Juliet O'Neill. 2008. Opposition leaders sign accord to form coalition government. Canwest News Service, 1 December. Available at: http://www.nationalpost.com/news/ canada/politics/story.html?id=1017301\#ixzz0c9aF6oW1.

Angus Reid Strategies. 2008. Political crisis splits views in Canada. 3 December. Available at: http://www.angusreid.com/polls/view/32364/political crisis splits views in canada/.

Bakvis, Herman, ed. 1991. Research Studies of the Royal Commission on Electoral Reform and Party Financing, Vol. 15. Toronto: Dundurn Press. 
Behiels, Michael. 2010. Stephen Harper's rise to power: Will his 'new' Conservative Party become Canada's 'natural governing party' of the twenty-first century? American Review of Canadian Studies 40(1):118-145.

Blais, André. 2006. What affects voter turnout? Annual Review of Political Science 9:111-25.

Boswell, Randy. 2009. Governor General's new website adds fuel to head-ofstate debate. Canwest News Service, 9 October. Available at: http://www. nationalpost.com $/ \mathrm{m} /$ story.html?id=2087636

Brantingham, Paul and Patricia Brantingham. 1984. Patterns in Crime. New York: Macmillan Press.

Cameron, David R. 2009. Ultimately the system worked. In Peter Russell and Lorne Sossin, eds., Parliamentary Democracy in Crisis. Toronto: University of Toronto Press.

Chase, Steven, Bill Curry, and Clark Campbell. 2008. Tories take to airwaves; Greens back coalition. Globe and Mail, 2 December. Available at: http:// www.theglobeandmail.com/servlet/story/RTGAM.20081202.wPOLcoalition1202/BNStory/VideoLineup/

Clarke, Ronald V. 1997. Situational Crime Prevention: Successful Case Studies. Second edition. Albany, NY: Harrow and Heston.

Clarke, Ronald V. and Marcus Felson. 1993. Introduction: Criminology, routine activities, and rational choice. In R.V. Clarke and M. Felson, eds., Routine Activity and Rational Choice. Advances in Criminological Theory. Vol 5. New Brunswick, NJ: Transaction Books.

Clarke, Ronald, Graeme R. Newman, and R.V.G. Clarke. 2006. Outsmarting The Terrorists. Santa Barbara, CA: Praeger Security International.

Clarke, Ronald V. and David Lester. 1988. Suicide: Closing the Exits. New York: Springer-Verlag, Inc.

Clarkson, Adrienne. 2009. Foreword. In Peter Russell, and Lorne Sossin, eds., Parliamentary Democracy in Crisis. Toronto: University of Toronto Press.

Cohen, Andrew. 2007. The Unfinished Canadian: The People We Are. Toronto: McClelland \& Stewart.

Cohen, Carl. 1997. Communism, Fascism, and Democracy. Boston: McGraw Hill.

Cohen, Lawrence E. and Marcus Felson. 1979. Social change and crime rate trends: A routine activity approach. American Sociological Review 44(4):588-605.

Cornish, D. and R. Clarke. 1986. The Reasoning Criminal: Rational Choice Perspectives on Offending. The Hague, NL: Springer-Verlag.

Coyne, Andrew. 2009. What's at stake? Macleans Magazine, 31 December. Available at: http://www2.macleans.ca/2009/12/31/whats-at-stake/. 
CTV news staff. 2005. Gov. Gen. designate denies separatist link. 18 August. Retrieved 31 December 2009 from http://www.ctv.ca/servlet/ArticleNews/ story/CTVNews/20050817_jean_comments_050816/?hub=TopStories

Delacourt, Susan. 2010. GG and PM: Behind the scenes of the prorogation decision. Toronto Star, 3 October. Available at: http://www.thestar.com/ article/869915--gg-and-pm-behind-the-scenes-of-the-prorogation-deci$\underline{\text { sion }}$

Desserud, Donald. 2009. The Governor General, the Prime Minister, and the request to prorogue. Canadian Political Science Review 3(3):40-54.

Ekos Associates. 2008. Ekos Poll, 5 December. Available at: http://www.ekospolitics.com/index.php/2008/12/ekos-poll-december-5-2008/.

Elections Canada. 2009. Voter Turnout at Federal Elections and Referendums, 1867-2008. Available at http://www.elections.ca/content.asp?section=pa $\underline{\text { s\&document }=\text { turnout\&lang }=\mathrm{e}}$

Felson, Marcus and Joe Spaeth. 1978. Community structure and collaborative consumption: A routine activity approach to consumer behavior. American Behavioral Scientist 21:614-624.

Flanagan, Tom. 2009. Only voters have the right to decide on the coalition. Globe and Mail, 9 January. Available at: http://www.theglobeandmail. com/news/politics/article963810.ece

Foley, Michael. 2000. The British Presidency. Manchester: Manchester University Press.

Foot, Richard. 2009. Withering of parliament. Canwest News Service, 15 January Retrieved Jan 52010 from http://www.canada.com/news/story. $\underline{\mathrm{html} \text { ?id }=1160170}$ 2010. Only in Canada: Harper's prorogation is a Canadian thing. CanWest News Service, 8 January. Retrieved Nov 30, 2010 from http://www. nationalpost.com/Only + Canada + Harper + prorogation + Canadian + thi $\underline{\text { ng/2446705/story.html }}$

Forsey, Eugene. 1943. The Royal Power of dissolution of Parliament in the British Commonwealth. Toronto: Oxford University Press.

1953. The Crown and the constitution. Dalhousie Review 33:31-46.

1967. Constitutional monarchy and the provinces: The confederation challenge. Pp 21-32 in Eugene Forsey, ed., Freedom and Order: Collected Essays. Toronto: McClelland and Stewart.

1974. Freedom and Order: Collected Essays. Toronto: McClelland and Stewart.

1990. The present position of the reserve powers of the Crown. In H.V. Evatt and E.A. Forsey, Evatt and Forsey on the Reserve Powers. Sydney, AU: Legal Books.

2010. How Canadians Govern Themselves ( $7^{\text {th }}$ Edition) Ottawa: Library of Parliament.

Forsey, Helen. 2009. Crisis of ignorance is addressed: Correcting widespread myths about our parliamentary system. The CCPA Monitor Jul/Aug 2009 
Franks, Ned. 2009. To prorogue or not prorogue: Did the Governor General make the right decision? In Peter Russell and Lorne Sossin, eds, Parliamentary Democracy in Crisis. Toronto: University of Toronto Press.

Fraser, Graham. 1998. Qu'est-ce que la francophobie au Canada? Le Devoir, 3 December.

Garland, David. 2001. The Culture of Control. London: Oxford University Press.

Gieger, John. 2008. Globe editorial board editor on why Harper should resign. Globe and Mail, 2 December. Available at: http://www.theglobeandmail. com/news/opinions/article725330.ece.

Haggerty, Kevin D. 2004. Displaced expertise: Three constraints on the policyrelevance of criminological thought. Theoretical Criminology 8(2):211231.

Heard, Andrew. 2009. The Governor General's decision to prorogue parliament: A chronology and assessment. Constitutional Forum 18(1):1-11. 2010. Give the House the authority. Globe and Mail, 12 January. Available at: http://www.theglobeandmail.com/news/opinions/give-thehouse-the-authority/article1426031/.

Heidt, Jon M. 2003. The growth of criminological theories. Masters Thesis, Simon Fraser University, Burnaby, BC.

Hirschi, Travis. 1989. Exploring alternatives to integrated theory. Pp. 37-50 in S. Messner, M. Krohn and A. Liska, eds., Theoretical Integration in the Study of Deviance and Crime: Problems and Prospects. Albany: NY: State University of New York.

Hogg, Peter. 2010. Did the Governor-General make a wise decision? National Journal of Constitutional Law 27(1):193-203.

2007. Constitutional Law of Canada. Toronto: Thompson Carswell.

Horwitt, Sanford. 1999. New Millennium Project: American youth attitudes on Politics, Citizenship, Government, and Voting. Lexington, KY: National Association of Secretaries of State.

Jackman Robert W. 1987. Political institutions and voter turnout in industrial democracies. American Political Science Review 81:405-24.

Jacobs, Jane. 1961. The Death and Life of Great American Cities. New York: Random House.

Kay, Jonathan. 2008. Six reasons that Stephen Harper should gladly let Stéphane Dion take his job. National Post, 1 December. Available at: http:// network.nationalpost.com/np/blogs/fullcomment/archive/2008/12/01/ jonathan-kay-six-reasons-that-stephen-harper-should-gladly-let-st-233phane-dion-take-his-job.aspx

Klein, Alice. 2009. Politics with Don Newman. 24 September. Available at http:// www.rabble.ca/columnists/2009/09/politics-don-newman.

LeClair, Jean and Jean-François Gaudreault-DesBiens. 2009. Of representation, democracy, and legal principles: Thinking about the impensé. In Peter 
Russell and Lorne Sossin, eds., Parliamentary Democracy in Crisis. Toronto: University of Toronto Press.

Leavitt, Glen. 1999. Criminological theory as an art form: Implications for criminal justice policy. Crime \& Delinquency 45(3):389-399.

Levy, Gary. 2009. A crisis not made in a day. In Peter Russell and Lorne Sossin, eds., Parliamentary Democracy in Crisis. Toronto: University of Toronto Press.

Martin, Don. 2008. Too late to change course? Canwest News Service, 3 December. Available at: http://www.canada.com/story.html?id=1023457.

Martin, Lawrence. 2010. Harperland: The Politics of Control. Toronto: Viking Press.

McWhinney, Ted. 2005. The Governor General and the Prime Ministers: The Making and Unmaking of Governments. Vancouver: Ronsdale Press.

Meier, Robert. F. and Terence D. Miethe. 1993. Understanding theories of criminal victimization. Pp. 459-499 in M. Tonry, ed., Crime and Justice: A Review of Research. Vol. 17. Chicago: University of Chicago Press.

Mercer, Rick. 2008. It's not the economy, stupid. Globe and Mail, 6 December. Available at: http://www.theglobeandmail.com/news/politics/article726205.ece.

Miller, Bradley. 2009. Proroguing parliament: A matter of convention. Public Law Review 20:100-108.

Miller, Mitchell, Christopher Schreck, and Richard Tewksbury. 2007. Criminological Theory: A Brief Introduction. 2nd Edition. Reading, MA: Addison-Wesley.

Newman, Oscar. 1972. Defensible Space: People and Design in the Violent City. New York: MacMillan.

O’Malley, Kady. 2008. A trip down minority government memory.Maclean's Magazine, 28 November. Available at: http://www2.macleans. ca/2008/11/28/a-trip-down-minority-government-memory-lane/

Pilon, Dennis. 2007. The Politics of Voting: Reforming Canada's Electoral System. Toronto: Emond Montgomery Publications.

Potter, Andrew. 2009. Unbalanced thoughts: Essays about last fall's Ottawa showdown highlight only the values of parliamentary tradition. Canadian Literary Review, July 1. Available at: http://reviewcanada.ca/reviews/2009/07/01/unbalanced-thoughts/.

Potvin, Maryse. 2000. Some racist slips about Quebec in English Canada between 1995 and 1998. Canadian Ethnic Studies 42(2):1-26.

Powell, Bingham, G., Jr. 1986. American voter turnout in comparative perspective. American Political Science Review 80(1):17-43.

Putnam, Robert. 2000. Bowling Alone: The Collapse and Revival of American Community. New York: Simon \& Schuster. 
Roberts, Edward. 2009. Ensuring constitutional wisdom during unconventional times. Canadian Parliamentary Review Spring 2009:13-17.

Robinson, Matthew. 2004. Why Crime? An Integrated Systems Theory of Antisocial Behavior. Upper Saddle River, NJ: Prentice Hall.

Rorty, Richard. 1999. Philosophy and Social Hope. London: Penguin Publishers.

Russell, Peter. 2008. Two Cheers for Minority Government: The Evolution of Canadian Parliamentary Democracy. Toronto: Emond Montgomery Publication Limited.

2009. The Need for Agreement on Fundamental Conventions of Parliamentary Democracy. (Unpublished Manuscript) University of Toronto

Russell, Peter and Lorne Sossin, eds. 2009. Parliamentary Democracy in Crisis. Toronto: University of Toronto Press.

Scoffield, Heather. 2010. Governor-general is not a political referee, David Johnston says. The Canadian Press, 6 October, Ottawa. Available at: http:// www.theglobeandmail.com/news/politics/governor-general-is-not-apolitical-referee-david-johnston-says/article1746231/singlepage/

Simpson, Jeffrey. 2009. If you really want a coalition, do it the German way. 8 December. Available at: http://www.theglobeandmail.com/news/opinions/ if-you-really-want-a-coalition-do-it-the-german-way/article1393289/.

Skogstad, Grace. 2009. Western Canada and the "illegitimacy" of the LiberalNDP coalition government. In Peter Russell and Lorne Sossin, eds., Parliamentary Democracy in Crisis. Toronto: University of Toronto Press.

Slattery, Brian. 2009. Why the Governor General matters. In Peter Russell and Lorne Sossin, eds., Parliamentary Democracy in Crisis. Toronto: University of Toronto Press.

Smith, David. 2007. The Peoples House of Commons. Toronto: University of Toronto Press.

Smith, Jennifer. 2009. Parliamentary democracy versus faux populist democracy. In Peter Russell and Lorne Sossin, eds., Parliamentary Democracy in Crisis. Toronto: University of Toronto Press.

Sossin, Lorne and Adam Dodek. 2009. When silence isn't golden: Constitutional conventions, constitutional culture, and the Governor General. In Peter Russell and Lorne Sossin, eds., Parliamentary Democracy in Crisis. Toronto: University of Toronto Press.

Stilborn, Jack. 2009. The role of the Governor General: Time to revisit the visits. Policy Options July/August.

Taber, Jane. 2010. Laureen Harper persuaded Governor-General's wife into role. Globe and Mail, 15 October. Available at: http://www.theglobeandmail. com/news/politics/ottawa-notebook/laureen-harper-persuaded-governor-generals-wife-into-role/article1760060/

Teixeira, Ruy A. 1992. The Vanishing American Voter. Washington, DC: Brooking Institute Press. 
Tibbetts, Janice. 2008. The Governor General's options in this week of political crisis. Canwest News Service, 1 December. Available at: http://www.canada.com/topics/news/national/story.html?id=1018272

Topp, Brian. 2009. Things fall apart. Globe and Mail, 3 December. Available at: http://www.theglobeandmail.com/blogs/brian-topp/coalition-reduxthings-fall-apart/article1387799/

Weinrib, Lorraine. 2009. Prime Minister Harper's parliamentary 'time out': A constitutional revolution in the making? In Peter Russell and Lorne Sossin, eds., Parliamentary Democracy in Crisis. Toronto: University of Toronto Press.

Wheeldon, Johannes. 2009. Toward common ground: Restorative justice and its theoretical construction(s). Contemporary Justice Review 12(1):

Wheeldon, Johannes and Jon Heidt. 2007. Bridging the gap: A pragmatic approach to understanding critical criminologies and policy influence. Critical Criminology 15(4):

Whitley, James. 2001. Ministerial error and the political process: Is there a duty to resign? Sheldon Chumir Foundation for Ethics in Leadership, Calgary, AM Available at: http://www.chumirethicsfoundation.ca/main/page. php?page id $=98$

Whittington, Les, Bruce Campion-Smith, and Tonda MacCharles. 2008. Liberals, NDP and Bloc sign coalition pact. The Star Newspaper, 1 December. Available at: http://www.thestar.com/news/canada/article/546315

Wilson, James Q. 1975. Thinking about Crime. New York: Basic Books.

Winsor, Hugh. 1997. Race-hate ads add a nasty new flavour to Canada poll. Independent Newspaper, 27 May. Available at: http://www.independent.co.uk/news/world/racehate-ads-add-a-nasty-new-flavour-to-canadapoll-1263725.html 
